\title{
Research on the Credit Index System of Small and Micro Enterprises Based on Inclusive Finance
}

\author{
Qian $\mathrm{Shi}^{1, *}$ \\ ${ }^{1}$ School of Economics and Management, Jiangsu University of Science \& Technology, Zhenjiang, Jiangsu 212003, \\ China \\ *Corresponding author. Email: 1528018173@qq.com
}

\begin{abstract}
As the main service object of inclusive finance, the financing problem of small and micro enterprises has not been effectively solved although it has been widely concerned. In the current situation of imperfect development of the credit industry in China, the construction of the credit index system of small and micro enterprises based on inclusive finance can not only promote the development of inclusive finance, but also promote the establishment of unified standards for the credit industry, and effectively alleviate the financing difficulties of small and micro enterprises, and kill three things with one stone. From the perspective of inclusive finance, this paper constructs a credit index system based on the credit index system of relevant institutions at home and abroad and the characteristics of small and micro enterprises.
\end{abstract}

Keywords: inclusive finance, small and micro enterprises, credit indicator system

\section{INTRODUCTION}

Inclusive finance is put forward in 2005 by the United Nations, it is to point to to have financial services at affordable cost to various social strata and groups provide appropriate and effective financial services, it is the most important connotation is everyone financial beneficiaries, this among them, the small micro enterprises, farmers and other vulnerable groups is the key of the it service object. It should be noted that although the focus of inclusive finance is to serve the disadvantaged groups to promote social equity, it is not a public welfare activity. Pan Guangwei party secretary of the China banking association, points out that pratt \&whitney financial should be to provide financial services to the community, especially for small micro enterprise, farmers and other vulnerable groups to provide equal financial services, adhere to the combination of marketization and policy support, in order to bring benefit to both sides of supply and demand, to ensure a healthy business sustainable development[1].

\subsection{The definition of small and micro enterprises}

The content of this paper is the credit index system of small and micro enterprises under inclusive finance. The target group is small and micro enterprises. At present, in China, small and micro enterprises are considered as small enterprises, micro enterprises, home-based enterprises and individual businesses[2]. The content of this paper is the credit index system of small and micro enterprises under inclusive finance. The target group is small and micro enterprises. At present, in China, small and micro enterprises are considered as small enterprises, micro enterprises, home-based enterprises and individual businesses. In June 2011, the ministry of industry and information technology and other departments issued the "regulations on the classification of small and medium-sized enterprises", which divided small and medium-sized enterprises into medium, small and micro enterprises, and defined the size of enterprises according to corresponding indicators for different industries.

From this document we can see that, the most intuitive characteristics of small and micro enterprises are small scale, fewer employees, relatively small total amount of operating assets, property rights and management rights highly unified. In addition, small and micro enterprises also have the following characteristics: 1. Low entry threshold, high sensitivity to the market, weak stability; 2 . The demand for financing is short in term, high in frequency, and small in amount, which makes it easy for urgent loans to be repaid; 3 . The financial system is not perfect at present.

\subsection{The current situation and reasons of MSMEs in the process of financial inclusion}

In recent years, China's various government departments also issued relevant policy promote the pratt \&whitney financial. Starting from October 1, 2014, the threshold for value-added tax and business tax for small and micro enterprises was raised to 30,000 yuan. The executive meeting of the state council held on February 25, 2015 raised the standard of tax on small and micro enterprises by half to 200,000 yuan. On November 7, 2017, Premier $\mathrm{Li}$ Keqiang made important remarks on the national financial service teleconference for small and micro businesses. The remarks pointed out that small and micro businesses enjoy prosperous employment and economic prosperity. At present, the data released by the state 
administration of taxation shows that tax reductions under preferential policies for small and micro businesses exceeded 100 billion yuan in 2015 and 2016. Although the state has successively introduced policies to support the development of small and micro enterprises, and achieved some results, such as the implementation of the "no less than three" requirement, the financing status of small and micro enterprises is still not optimistic[3]. At present, the financing of small and micro enterprises is still dominated by bank loans and private lending, with high financing costs and financing difficulties. The reasons for this situation are as follows: 1. China's existing financial institutions, such as Banks, have obvious preferential policies. 2. Small and micro enterprises have insufficient innate conditions: they generally have small production scale, little fixed assets, insufficient collateral and weak ability to resist risks. Meanwhile, the financial system is not sound and the management philosophy of managers is uneven. 3 . The direct financing threshold is high, the cost is high, the term is long, and the application process is complex: many small and micro enterprises are highly sensitive to the market, and the long term of direct financing and the complicated procedures may cause small and micro enterprises to miss the business opportunities, which makes it difficult for them to survive; 4, imperfect credit environment, financial institutions in lending is usually the borrower's credit data obtained from the central bank, however, tend to lack the small micro enterprise credit records, information asymmetry on the other hand lead to financial institutions is difficult to judge small micro enterprise repayment ability which could lose some of their business, on the other hand lead to small micro enterprise is difficult to get loans. To sum up, small micro enterprise financing difficulties of the most important reason is the imperfect credit environment caused by asymmetric information, establish a perfect public recognition credit evaluation index system, convenient for investors, can also urged small micro enterprises to improve their credit index and the improvement of the spontaneous and standardize itself, forming a virtuous cycle.

\section{RESEARCH ON CREDIT INDEX SYSTEM OF SMALL AND MICRO ENTERPRIES}

\subsection{The analysis and reference of the credit index system of foreign credit institutions}

The concept of credit evaluation has a long history of development in foreign countries. Compared with China, the research and application of credit index system of enterprises are more mature, including moody's, standard \& poor's, dun $\&$ bradstreet, fitch and other well-known institutions. Among them, Dun \& Bradstreet is a credit management company focusing on enterprise credit. Its scale, popularity and long history make it a giant in the enterprise credit industry. In addition, compared with standard \& poor's and moody's, $\mathrm{d} \& \mathrm{~b}$ focuses more on the government and enterprises with larger market scale, while $d \& b$ focuses more on small and medium-sized enterprises. Therefore, for small and micro enterprises, $d \& b$ 's credit index system is more worthy of exploration and reference[4].

The basic points of credit evaluation of enterprises by $d \& b$ include business information and geographic information, financial information, payment information and public records, which respectively reflect the operating status, financial status and repayment intention of enterprises. Among them, it stipulates that business information accounts for $52 \%$, geographic information accounts for $9 \%$, financial information accounts for $26 \%$, payment information accounts for $8 \%$, and public records accounts for $5 \%$. Each of its elements contains various indicators, such as its financial information including current ratio, quick ratio, equity ratio, net profit ratio, return on equity, profit margin on assets, accounts receivable turnover rate and other indicators. It is through the index system composed of these indicators that $d \& b$ analyzes the comprehensive situation of the enterprise and gives the rating results. It is worth noting that $d \& b$ has the highest comprehensive database of its kind in the world, and its analysis is not only inseparable from the qualitative analysis of professionals, but also from the quantitative analysis based on its huge database.

\subsection{Status quo of credit index system of small and micro enterprises in China}

At present, the following problems still exist in the construction of credit index system of small and micro enterprises in China:

\subsubsection{The subject is chaotic and lacks independence}

The main body here is the main body of establishing the credit index system of small and micro enterprises. Driven by their respective interests, ICBC, China construction bank and other financial institutions as well as customs departments have their own established enterprise credit index system. Their index systems are different in many aspects, such as information scope, evaluation standard and evaluation method, etc. The lack of industry unified standards leads to obvious differences in their index systems. The most intuitive point is that they have great differences in the content and classification of the indicator system, taking ICBC and CCB as examples (see table 1) 
Table 1 Classification standards of small and micro enterprises

\begin{tabular}{|c|c|c|}
\hline $\begin{array}{c}\text { Content of } \\
\text { index system }\end{array}$ & $\begin{array}{c}\text { ICBC } \\
\text { Shareholders' situation, economic } \\
\text { conditions, development prospects, } \\
\text { solvency }\end{array}$ & $\begin{array}{c}\text { Account risk, account behavior, qualitative } \\
\text { evaluation, special adjustment }\end{array}$ \\
\hline $\begin{array}{c}\text { Classification } \\
\text { of index } \\
\text { system }\end{array}$ & $\begin{array}{c}\text { 1. Small enterprises whose operating } \\
\text { period is less than one year } \\
\text { 2. Newly opened small enterprises } \\
\text { whose operating period is more than } \\
\text { one year }\end{array}$ & $\begin{array}{c}\text { 1. Small real estate enterprises } \\
\text { 2. New small businesses } \\
\text { 3. General small enterprises (annual sales } \\
\text { revenue less than 30 million yuan) } \\
\text { 4, general small enterprises (annual sales } \\
\text { revenue is greater than or equal to 30 } \\
\text { million yuan }\end{array}$ \\
$\begin{array}{c}\text { enterprises whose operating period } \\
\text { exceeds one year }\end{array}$ & $\begin{array}{c}\text { 5. Manufacturing, wholesale and retail, } \\
\text { construction and other industries) }\end{array}$ \\
\hline
\end{tabular}

These obvious differences show the reality of independent governance in China's credit market. They also make information users doubt the evaluation results and hinder the credit evaluation system of professional credit institutions (such as zhongxin international credit rating co., LTD., dagong international credit rating co., LTD.). The most important is that the primary principles of credit evaluation are objectivity, independence and impartiality. These evaluation index systems attached to financial institutions are inevitably biased, so their neutrality cannot be guaranteed.

\subsubsection{Relevant laws, regulations and supervision are not sound}

The construction of laws and regulations in China is still developing, and the credit legislation has not been perfected. There is no relevant legal basis for the collection and use of data, the management of evaluation industry, the application of credit indicator system, etc., which directly or indirectly leads to the problems such as the inability to meet the demand of credit market and the inability of enterprises to be effectively punished by law. Of course, in recent years, the relevant departments and associations in China have increasingly attached importance to the credit industry and issued relevant regulations.

The China insurance regulatory commission in the interim measures for the investment of insurance funds in bonds, investment in different bonds have requirements, including credit requirements, for example, in view of the commercial Banks to issue financial corporate bonds, it shall meet the conditions is one of the domestic credit rating agencies assess A level or equivalent to A level above the long-term credit rating; Overseas listing and exempt from domestic credit rating, international credit rating agencies rated $\mathrm{BB}$ or equivalent to $\mathrm{BB}$ or above the long-term credit rating[5].

In terms of supervision, there are several large credit rating agencies in China, which will evaluate the credit of enterprises, but the public recognition of their evaluation results is not enough, one of the main reasons is the lack of supervision. In 2011, the China banking regulatory commission issued the "guidelines for the China banking regulatory commission about commercial Banks use external credit rating notice, the notice of the stressed the" commercial Banks shall be prudent to use external credit rating, should not be directly as a credit on the basis of external rating, and shall appoint professional department is responsible for in the credit business process management at the use of external credit rating ", "used by commercial Banks to deal with external agencies to make the necessary due diligence, review its independence, professionalism and credibility rating"[6]. Thus, China has a long way to go in supervising the professional credit rating agencies and the credit index system they use.

\subsubsection{The related talent team is insufficient and the technology needs to be improved}

In China, the credit industry belongs to a relatively new industry, and the professional talent team is still immature, and the practitioners' professional knowledge, business ability, moral ethics and analytical level are uneven. In the qualitative analysis of credit indicators, there is a strong dependence on the professional level of practitioners, the shortage of talents and the level of practitioners will directly affect the results of credit index analysis. In the quantitative analysis of credit indicators, the use of data is an indispensable link. In this era of "big things cloud shift", the technology development level is changing with each passing day. Therefore, it is the development of the credit industry to keep up with the development of The Times, improve the existing technology and apply it to practice.

\subsection{The significance of constructing credit index system of small and micro enterprises based on inclusive finance}

The inclusive financial system is an important part of the multi-level financial system, and small and micro enterprises are also an important part of the socialist market economy. The significance of constructing the credit index system of small and micro enterprises based on inclusive finance is reflected in the following aspects: 
1. Improve the financing difficulties of small and micro enterprises;

A credit index system widely recognized and accepted by the public can effectively improve the problem of information asymmetry, which not only reduces the cost and risk of lending by Banks and other financial institutions, but also improves the financing efficiency of small and micro enterprises, playing an important role in the healthy development of small and micro enterprises and even the market economy.

2. Provide practical experience for the establishment of the industry unified standards of China's credit index system;

Based on the current situation that the credit index system of small and micro enterprises in China is constructed in a chaotic way, and the laws, regulations and supervision are not perfect, it is urgent for China to establish a unified standard for the credit industry to regulate the market and provide guidance for credit evaluation institutions. In the process of inclusive finance, the establishment of credit index system and practice for small and micro enterprises can provide practical experience for the establishment of industry standards.

3. Promote the further development of inclusive finance;

Inclusive finance provides effective financial services, and sometimes, financial support is just to give people fish, building a widely recognized credit index system is undoubtedly to give people fish, compared with direct financial support, it is more effective, more in line with the concept of inclusive finance, conducive to the development of inclusive finance.

4. Provide guidance for small and micro enterprises to improve themselves;

Small and micro enterprises often have their own financial system is not sound, the management concept of managers is not scientific, the construction of a credit index system for small and micro enterprises to facilitate the owners and managers of small and micro enterprises to find their own shortcomings according to the index, improve themselves, in order to improve their credit.

\section{CONSTRUCT CREDITINDEX SYSTEMOF SMALLAND MICRO ENTERPRISES BASED ON INCLUSIVE FINANCE}

\subsection{Principles of selecting indicators}

1. The principle of combining qualitative and quantitative analysis

Qualitative analysis is based on the subjective judgment of professionals, while quantitative analysis is based on the actual data.

2. Pertinence principle

There is a huge difference between small and micro enterprises and large and medium-sized enterprises. The selection of indicators should be targeted at small and micro enterprises and based on their own characteristics.

3. The principle of both internal and external environment
In the process of selecting indicators, when considering the factors of small and micro enterprises themselves, the external environmental factors also need to be considered.

4. Representativeness principle

The more the indicators, the more comprehensive they are, the more likely there is a correlation between them, and the more the indicators, the more difficult it will be for us to comprehensively assess the credit of small and micro enterprises. Zhao lingyun used principal component analysis to extract four principal components from nine financial indicators through the financial data of ten listed companies[7]. Li pinghai also used principal component analysis and factor analysis to select financial indicators when studying whether transnational mergers and acquisitions can improve performance[8]. Therefore, the selection of indicators should be representative, which not only facilitates the credit evaluation of small and micro enterprises, but also makes the credit indicator system clearer and easier to understand.

5. The principle of combining solvency with willingness The establishment of the credit index system of small and micro enterprises is an effective work to promote the process of inclusive finance. The most important goal is to facilitate the financing of small and micro enterprises. However, often because of its small micro enterprises set up time is short, the incomplete financial system is difficult to get the data, thus on the one hand, through its mortgage, pledge, guarantee, such as index to judge its solvency, on the other hand through a small micro enterprise bank information and administrative information such as non-bank information combined with owner's personal credit judgment debt repayment willingness.

6. Data accessibility principle

The data of small and micro enterprises are not as perfect as those of listed companies, so the indicators that are easy to obtain should be selected.

\subsection{Reference source of indicators}

1. Index system of typical foreign credit rating agencies: standard \& poor's, moody's, d\&b, Japan bank of 8000

2. Credit index system of domestic commercial Banks for small enterprises: industrial and commercial bank of China, China construction bank

3. Related academic papers

\subsection{The construction of index system}

This paper divides the index system into two parts, one is qualitative analysis, the other is quantitative analysis. Qualitative analysis also includes the external environment of the enterprise, the internal situation of the enterprise, the past credit of the enterprise; Quantitative analysis includes enterprise debt paying ability, enterprise growth ability. 


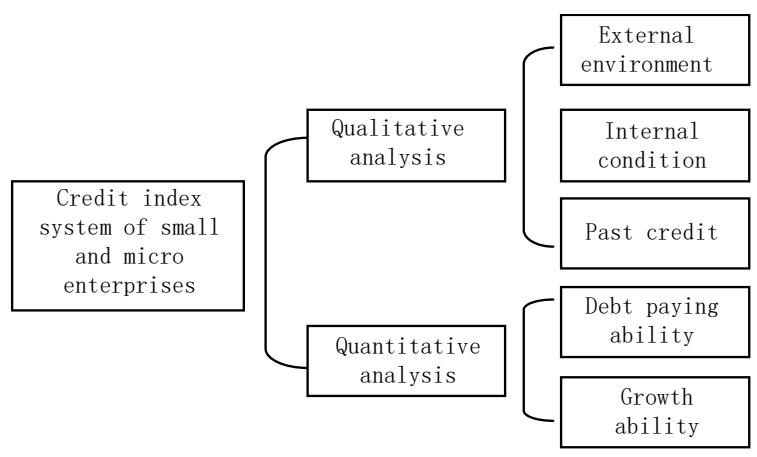

Figure 1 The credit index system of small and micro enterprises

To sum up, we use tables to reflect the credit index system of small and micro enterprises (see table 2).

Figure 1 The credit index system of small and micro enterprises

Table 2 Credit index system of small and micro enterprises

\begin{tabular}{|c|c|c|c|}
\hline \multicolumn{3}{|c|}{ Structure } & Indicators \\
\hline \multirow{27}{*}{$\begin{array}{c}\text { Credit index } \\
\text { system of } \\
\text { small and } \\
\text { micro } \\
\text { enterprises }\end{array}$} & \multirow{13}{*}{$\begin{array}{l}\text { Qualitative } \\
\text { indicators }\end{array}$} & \multirow{5}{*}{$\begin{array}{c}\text { External } \\
\text { environment }\end{array}$} & Policy support \\
\hline & & & Market supply and demand \\
\hline & & & Market competition \\
\hline & & & Market economic environment \\
\hline & & & Industry development potential \\
\hline & & \multirow{4}{*}{$\begin{array}{l}\text { Internal } \\
\text { condition }\end{array}$} & Economic strength of owners \\
\hline & & & Manager ability \\
\hline & & & Internal system of the enterprise \\
\hline & & & Future planning of the enterprise \\
\hline & & \multirow[t]{4}{*}{ Past credit } & Corporate past bank credit \\
\hline & & & Past government information of the enterprise \\
\hline & & & $\begin{array}{c}\text { Personal credit of the actual controller (natural person or } \\
\text { enterprise legal person) }\end{array}$ \\
\hline & & & Business credit of the enterprise \\
\hline & \multirow{14}{*}{$\begin{array}{l}\text { Quantitative } \\
\text { indicators }\end{array}$} & \multirow{6}{*}{$\begin{array}{l}\text { Debt paying } \\
\text { ability }\end{array}$} & Paid-in capital of an enterprise \\
\hline & & & Asset-liability ratio \\
\hline & & & Interest protection multiple \\
\hline & & & Current ratio \\
\hline & & & Quick ratio \\
\hline & & & Guarantee ability \\
\hline & & \multirow[t]{8}{*}{ Growth ability } & Return on net assets \\
\hline & & & Growth rate of main business revenue \\
\hline & & & Total asset expansion rate \\
\hline & & & Growth rate of operating profit \\
\hline & & & Accounts receivable turnover rate \\
\hline & & & Turnover rate of current assets \\
\hline & & & Profit margin of main business \\
\hline & & & Tax payment \\
\hline
\end{tabular}

\section{CONCLUSION}




\subsection{The research conclusion}

The establishment of a set of systematic and scientific credit index system for small and micro enterprises is of great significance for promoting inclusive finance and improving the financing difficulties of small and micro enterprises. The innovation of this paper is to construct a credit index system for small and micro enterprises based on inclusive finance from the perspective of inclusive finance. It is difficult to scientifically quantify the credit risk of small and micro enterprises in China when there is no unified industrial standard in the credit index system of small and micro enterprises. Based on the essence of inclusive finance, this paper constructs a credit index system for small and micro enterprises by integrating the credit index system of internationally renowned rating agencies and the credit index system of domestic commercial Banks for small enterprises. The index system divides the indicators into quantitative analysis and qualitative analysis, and subdivides the indicators into five categories: external environment, internal situation, past credit, debt paying ability and growth ability, a total of 27 indicators. It comprehensively and comprehensively considers the overall situation and characteristics of small and micro enterprises, and also reflects the principle of index selection.

At the same time, there are still shortcomings in this paper. This index system needs to establish a model for empirical research, determine the weight of the index in the model and test the feasibility of this index system.

\subsection{Policy recommendations are prospects}

In the process of promoting inclusive finance in China, it is better to establish a credit evaluation index system widely recognized by the public and establish a database of information of small and micro enterprises led by the national government than to increase the capital input to small and micro enterprises. Through the indicator system, the evaluation model can be established and the evaluation standard can be finally obtained, which not only facilitates the investment of investors, but also reduces the lending cost of the lending institution, and urges the small and micro enterprises to improve and standardize themselves to improve their credit rating in order to obtain financing, thus forming a virtuous circle.
[1] Pan Guangwei. Banking Pratt New Financial Results [J]. China's Financial,2017(22): 20-22.

[2] Yu Yang. Research on Financing Problems of Small and Micro Enterprises in China [D]. Jilin university,2013.

[ 3 ] Gong Hongguo, Zeng Guoan. Solving the Difficulty and High Cost of Financing For Small and Micro Businesses by Deepening Reform [N]. People's Daily, 2018-01-19 (07).

[4] Xu Guangjun, Ni Xiaohua, Xiao Yunxiang. Comparative Study on Index System of Enterprise Credit Evaluation of Standard \& Poor's, Moody's and Deng \& Bradstreet [J]. Zhejiang Finance, 2007 (03): 51-52.

[5] China Insurance Regulatory Commission. Interim Measures on the Investment of Insurance Funds in Bonds [Z], 2012-07-16.

[6] China Banking Regulatory Commission. Notice of China Banking Regulatory Commission on Regulating the Use of External Credit Rating by Commercial Banks [Z], 2011-01-26.

[7] Zhao Lingyun, Liu Wenhuan. Application of Principal Component Analysis in Comprehensive Evaluation of Financial Indicators [J]. Accountant, 2008 (10): 35-38.

[8] Li Pinghai, Zhu Wenjuan, Li Yao. Empirical Study on the Performance of Transnational Mergers and Acquisitions of Listed Companies in China based on Factor Analysis [J]. Sanjing Review, 2010 (03): 140-148.

\section{REFERENCES}

